\title{
Teachers as a panopticon for smart class students during distance learning
}

\section{Guru sebagai panopticon bagi murid smart class pada pembelajaran jarak jauh}

\author{
Eka Rizki Rahmawati ${ }^{\bowtie}$ \& Tuti Budirahayu \\ Department of Sociology, Faculty of Social and Political Sciences, Universitas Airlangga \\ Surabaya, 60286, East Java, Indonesia \\ E-mail of corresponding author: rizkiekarahmawati24@gmail.com
}

\begin{abstract}
The education sector is experiencing the impact of the COVID-19 pandemic, resulting in the implementation of the distance learning (PJJ) system to reduce the risk of virus transmission. This system, however, has several obstacles, including the internet network, social inequality, uncertainty in choosing the appropriate learning method, and the decline in student achievement. This problem is also faced by smart class students at Hang Tuah Senior High School 2 of Sidoarjo, forcing its teachers to be able to create innovative learning and act actively to discipline their students. This study aimed to determine the teachers' role as a panopticon for smart class students during distance learning. The qualitative research method was implemented using Foucault's genealogical approach and the research informants were determined using the snowball technique. The results of this study reveal that the teachers' role as a panopticon for the students is carried out with a hierarchical observation, giving reward and punishment, and repeated test system. This study concludes that the role of the teachers as a panopticon during distance learning at Hang Tuah Senior High School 2 of Sidoarjo is particularly useful for disciplining smart class students to carry out their obligations and prevent a decline in academic achievement even though the activities are done virtually.
\end{abstract}

Keywords: disciplining students; distance learning; panopticon; teachers

\begin{abstract}
Abstrak
Dunia pendidikan mengalami dampak dari adanya pandemi COVID-19 sehingga sistem pembelajaran jarak jauh (PJJ) harus dilakukan untuk mengurangi resiko penularan virus. PJJ ini memiliki banyak kendala yaitu jaringan internet, kesenjangan sosial, kebingungan memilih metode pembelajaran yang sesuai, dan penurunan prestasi murid. Permasalahan ini dialami juga oleh murid smart class SMA Hang Tuah 2 Sidoarjo sehingga guru harus mampu menciptakan pembelajaran inovatif dan berperan sebagai untuk mendisiplinkan murid. Studi ini bertujuan untuk mengetahui peran guru sebagai panopticon pada murid smart class selama PJJ. Metode penelitian kualitatif diimplementasikan dengan menggunakan pendekatan genealogi Foucault dan penentuan informan penelitian dilakukan menggunakan teknik snowball. Hasil studi ini mengungkapkan bahwa peran guru sebagai panopticon bagi murid dilakukan dengan sistem pengamatan bertingkat, memberikan reward dan hukuman, serta memberikan sistem ujian berulang. Studi ini menyimpulkan bahwa peran guru sebagai panopticon dalam PJJ di SMA Hang Tuah 2 Sidoarjo sangat berguna untuk mendisiplinkan murid smart class agar melakukan kewajiban dan tidak mengalami penurunan prestasi meskipun bertatap muka secara daring.
\end{abstract}

Kata Kunci: pendisiplinan diri murid; pembelajaran jarak jauh; panopticon; guru

\section{Introduction}

The COVID-19 pandemic, which has been devastating the world, including Indonesia, since 2020, has paralyzed many sectors, including education. The implementation of education in Indonesia has been disrupted from the middle of March 2020 until date, with students not being able to attend face to face directly, forcing learning to take place remotely or online. The learning process suddenly changes, causing many obstacles faced by teachers, students, even parents (AJI 2020). Due to the confusion in implementing education, the Ministry of Education and Culture issued a special curriculum for online learning, which is the Decree of the Minister of Education and Culture of the Republic of Indonesia Number 719/P/2020 concerning Curriculum Implementation Guidelines on Education Units in Special Conditions. Educational professionals are experimenting with various methods to ensure that education 
may progress despite not being able to meet face to face and that the younger generation does not lose the opportunity (Khasanah et al. 2020).

The decision to implement distance learning raises several obstacles because in many cases, some students do not own smartphones or laptops and have adequate internet access, prompting them to drop out of school. Moreover, the gap between students from rich families and students from low-income families is increasingly visible. Although the government has made a breakthrough by providing quota subsidies to teachers and students in schools and colleges, the policy cannot overcome the problem of education due to COVID-19. Furthermore, the spirit of learning among students during online learning is extremely different from that of offline learning, which tends to drop (Purnama 2021). This statement is in accordance with Triwiyanto's research (2020), stating that the low economic situation experienced by several families causing parents to be unable to meet children's educational needs despite the government's provision of a quota subsidy. Dunn et al. (2020) also stated that many parents are unable to provide educational opportunities for their children, so they have asked them to work to help them meet their daily needs. In addition, the need for high internet data packages causes some children to be often absent from online schools because the data packet assistance provided by the government is insufficient, and lack of financial ability to purchase data packages on their own (Azevedo et al. 2020). Students, teachers, and parents have seen a decline in mental health as a result of distance learning due to their unpreparedness in facing this pandemic (Pajarianto et al. 2020). Students experience stress because of the numerous assignments and their lack of understanding of the material presented by the teacher in the zoom meeting (Pfefferbaum \& North 2020). Education is a difficult task in the face of the COVID-19 pandemic because it necessitates direct engagement between teachers and students to impart not only the material but also the value and morals of life (Mahapara \& Sharma 2020). The impact of COVID-19 on education causes changes in the implementation of education and its main objectives must be adjusted gradually so that the younger generation does not lose the quality of education and remains a superior generation in the future (Aucejo et al. 2020).

According to Ningsih (2020), students experienced learning fatigue during the COVID-19 pandemic because they had difficulty understanding the material, the number of tasks assigned by the teacher, the absence of learning friends, and a lack of concentration due to the situation of the house, resulting in a decrease in student enthusiasm and achievement. Kurnia (2021) agreed that students experienced learning fatigue during online learning due to a reduced spirit of learning because of the condition of the house and a different learning environment. Learning motivation dropped rapidly since many students thought online learning was monotonous as compared to face-to-face meetings. Aswat et al. (2021) stated that the inhibiting factors of the development of the emotional intelligence of students during the online learning process are the lack of social activity, learning fatigue, the pressure from parents, a long learning process, stacking of tasks, and monotonous learning atmosphere. In addition, the achievement of learning outcomes is only related to the cognitive domain and character cultivation, and emotional intelligence obtained at home is not accompanied by socialization and innovative media support in inculcating emotional character in students.

Yanti \& Sumianto (2020) stated that students' interest in learning during the COVID-19 pandemic can not only be achieved with indicators of liking, enthusiasm, attention, and involvement, but also some of the factors including learning media provided by teachers, inadequate internet network especially at home, learning facilities, quality of learning, and parental support for students during the learning process. Rinawati \& Darisman (2020) stated that student boredom can be overcome in five ways, including increasing self-awareness, balancing rest time with the learning process, seeking support from the closest environment, and practicing mental training techniques.

These issues are experienced by almost every student who is currently undergoing distance learning, including in Hang Tuah Senior High School 2 of Sidoarjo. Based on official information from the website of Hang Tuah Senior High School 2 of Sidoarjo, this school also saw a drop in student achievement during online learning since many students became bored with the learning system. However, this school 
has started implementing a smart class program as a way to deal with learning in the pandemic era (Hang Tuah Senior High School 2 of Sidoarjo 2020). This program has been started by the government in 2018 to improve the 2013 curriculum and is contained in the Regulation of the Minister of Education and Culture of the Republic of Indonesia Number 36 of 2018 concerning Amendments to Ministerial Regulation Number 59 of 2014 which contains the 2013 curriculum for SMA/MA, stating that the development of the 2013 curriculum is carried out to facing external challenges including globalization and various issues related to environmental problems, advances in technology and information, the emergence of the creative industry, culture, and the development of education at the international level. The method used in the smart class is a combination of various techniques, including lectures, discussions, simulations, and practice.

In general, smart class learning has been designed by the government so that it has adaptive, normative, and productive materials in a technology-based space with approximately 30 students. To ensure that not just any student may enter this class, students will take a variety of academic assessments, including analogy, intelligence, basic computer skills, numerical ability and accuracy, and analytical reasoning tests. The facilities in this class are finger touch, portable interactive whiteboard, eduboard, Wi-Fi Protected Setup (WPS), and projector. This system allows teachers to control students using their laptops, and all forms of evaluations can be completed using tablets or mobile phones. Education in this class incorporates international material, which sets it apart from other classes. They are also taught soft skills so that they have abilities that can be used in the future.

In reality, the smart class program cannot completely make students obey the rules during online learning or PJJ because many students do not do assignments and are absent during online learning, resulting in a decline in some grades. Therefore, teachers and students need to maintain a good relationship during learning. In addition, there is a need for self-discipline initiated by the teacher so that students do not violate the rules that have been established during distance learning. This is a significant responsibility for the teachers because the smart class has students with above-average academic abilities. As a result, teachers must act as a panopticon for students during the distance learning process in order to maintain students' achievement.

Some relevant studies to the focus of this study are those carried out by Sari \& Hadijah (2017) which stated that self-discipline in humanist learning can be carried out by teachers by giving rewards when students get achievements and giving appropriate punishments when they make mistakes. It can be implemented by establishing class rules that are mutually agreed upon between teachers and students. All of this is done in order for students and teachers to create close relationships, not simply formally. Zaki (2018) stated that the learning process in the classroom also involves noble values and norms so that student self-discipline is carried out by the teacher to normalize the students' behavior of politeness towards teachers and older people because nowadays many teenagers underestimate this aspect. Moreover, Sunardi \& Fatihin (2019) stated that in the education process, a teacher is a person who can dynamically remind students not to behave negatively. Teachers are educators, mentors, and advisors for students throughout the education process, so they must be obeyed even though some of their advice is biased. Ilham \& Fauzi (2021) emphasized that discipline works with two methods, including panopticon and punishment. The form of supervision or panopticon in Islamic boarding school is carried out with routine activities of tadarus and dhuha prayers in the middle of a large field, allowing teachers to monitor student activities easier. The teachers stand at a higher place so that the viewing angle for supervising becomes wider. Supervision is also carried out by going around the field to ensure that each individual carries out ongoing activities so that students will always feel supervised when carrying out routine activities. Muzaenatun (2017) stated that the teachers' strategy in maximizing the supervisory function is to monitor but not limit the activities of students in the classroom. Teachers do not necessarily observe directly but through monitors connected to CCTV. Furthermore, the teacher reprimands the students for any mistakes made and if the problem persists, the teacher consults with Counseling Guidance and students to find a solution. All teachers are involved in monitoring and evaluation activities. Aprilia \& Jacky (2019) stated that the power of the school community to supervise school residents can be done 
by utilizing CCTV as a monitoring medium. The function of CCTV as a surveillance medium is shown in the form of a statement that aims to form a panopticon effect on students. In fact, depending on the concealed information that students possess, the power of the community elicits a distinct reaction from them. Students' reactions are a manifestation of their power, which is driven by their knowledge. This information comes from students' personal experiences with existing interest relationships.

Aini (2019) stated that the disciplinary practice applied at State Junior High School 11 of Madiun was carried out through the School Discipline Movement (GDS) program as a control program to build students' disciplined character. Discipline is practiced under the supervision of the vice-principal, student council, and counseling guidance (BK). Normalization is carried out with the GDS program and teachers are in charge of examinations. Marice \& Taqwa (2020) added that the disciplinary mechanism can be performed through supervision and monitoring by rewarding points that function as a panopticon that has the power to monitor the behavior of students in carrying out school activities. In addition, there are raids as monitoring that provide effectiveness to reduce the occurrence of violations. Normalization is carried out by implementing and enforcing punishment and reward as a controller of student behavior, which is useful for correcting and controlling student behavior. Disciplinary techniques are carried out with democratic discipline. In this study, Apriyanto (2019) stated that student discipline is realized through policy enforcement carried out by school principals, student affairs, homeroom teachers, teachers, members of IPNU (Ikatan Pelajar Nahdlatul Ulama), and IPPNU (Ikatan Pelajar Putri Nahdlatul Ulama). Meanwhile, the policy of applying fingerprint attendance system based on SMS gateway has not had positive implications, particularly for student discipline. A study conducted by Suryanto (2020) showed that Islamic boarding schools functioned as a micro-educational institution in achieving the ideal based on the Qur'an, hadith, and ijtihad scholars. Islamic boarding schools are used as a place to establish meaningful relationships between humans and the creator. Meanwhile, at a macro level, Islamic boarding schools can be seen as a certain area with a panoptic function. The buildings can serve as the center of discourse relations and are able to influence the behavior of those who live there.

According to Foucault (1975), discipline is the character of modern society, which is a process of changing the individual to be able to act according to the norms and values of society. It functions to control, correct, regulate, and monitor people using norms as standards. It is performed through three primary methods. First, the observation method is a strategy for gathering information and monitoring each individual's behaviors that are carried out by superiors or those in positions of power above them. The controlling principle is not a reality but a possibility to observe. The panopticon functions to be able to form a body that is obedient and can be controlled (Martono 2014, Mu'tamiroh \& Suyanto 2021). This observation is performed without the knowledge of the individuals being observed so that they do not realize that they are being the object observed at any time. Second, normalization or standardization is a method used to measure, classify, and categorize individuals according to particular standards or norms. Through normalization, an individual is not only judged by the good and wrong aspects but also judged by comparing to other individuals using certain standards. Third, the test system is modern power or knowledge combining power (ability, intelligence, and truth) in a unified whole (Foucault 2002). The test results are utilized to reward or punish the individuals through the same mechanism, including hierarchical observation and normalization of assessment. The examination system groups students into particular categories according to the assessment standards established by the school. This standard entirely separates students' abilities, analyzes individual competencies, ranks individual abilities, and provides training to individuals to improve their results (Gutting 2005).

This study is crucial to conduct because teachers' supervision must be improved through the panopticon system created by the teachers. Moreover, student discipline and obedience to teachers have started to decline since the implementation of distance learning, such as students' willingness to collect assignments on time, looseness for not wearing uniforms during online learning, unwillingness to turn on the camera, lack of student activity, being absent, and never attend the online meeting because of various reasons. In addition, the study is conducted to ensure that the main goal of the formation of smart classes as a program used to improve the quality of students and teachers as good partners in digital era 
education can be realized. This study aimed to determine the role of teachers in the smart class program as a panopticon for their students to maintain learning enthusiasm and student achievement during the distance learning period. Therefore, the formulation of the problem in this research is how do the teachers in the smart class program act as a panopticon for students during the distance learning period (PJJ) at Hang Tuah Senior High School 2 of Sidoarjo?

\section{Research Method}

This study employed a qualitative method with Foucault's genealogical approach to describe the construction of individuals as objects of knowledge and controlled subjects (Martono 2014). This construction is used to see practices related to body regulation, action regulation, and self-discipline that students have in the smart class to maintain their predicate as smart and disciplined students and as well as their position in the smart class (Ritzer \& Goodman 2014). The paradigm used was interpretative because the phenomenon was described differently for each individual. The research was carried out at Hang Tuah Senior High School 2 of Sidoarjo as one of the schools implementing a smart class in Sidoarjo Regency and is a pilot school for superior class based on the sophistication of informatics technology. The technique of determining informants is done by a snowball technique, namely the teacher who teaches in the smart class. The informants who were interviewed were six teachers and 2 additional informants of the counseling teachers as supporting data as provided in Table 1. Based on data obtained, of six teachers, two of them implement discipline by building good relationships with students, so students were happy to obey the rules during the online learning. Meanwhile, the other four teachers stated that the smart class students consist of students who are academically smart so that the threat of grades is extremely effective in making students obey and additional points are the best reward. In addition, the counseling teachers stated that students will be diligent in following online learning when the teachers can make students like the learning process, easy to give good grades, and give few assignments. However, when students do not like the teachers because of the way of teaching or giving grades, the students will rarely go online and do not collect assignments.

Table 1.

List of Informants

\begin{tabular}{cccc}
\hline No. & Name & Gender & Informant's characteristics \\
\hline 1 & DIJ & Female & Smart class teacher \\
2 & JEN & Female & Smart class teacher \\
3 & MUI & Male & Smart class teacher \\
4 & KHU & Female & Smart class teacher \\
5 & PRA & Female & Smart class teacher \\
6 & ROI & Male & Smart class teacher \\
7 & DIA & Female & Counseling teacher \\
8 & IWA & Male & Counseling teacher \\
\hline \multicolumn{3}{r}{}
\end{tabular}

The data collection technique was carried out by observing the state of distance learning at Hang Tuah Senior High School 2 of Sidoarjo. In-depth interviews with smart class teachers served as the primary data while secondary data were obtained from schools. The data analysis technique was carried out by categorizing and analyzing data according to the theoretical concept used in the study, which was Michel Foucault's panopticon. The conclusion was made by drawing answers to the research focus, which was the role of the teacher as a panopticon for students in the smart class based on the data that has been gathered and analyzed. 


\section{Results and Discussion}

Foucault's genealogy describes that in the relationship of power and knowledge carried out by teachers and students, there is obedience and practice of body regulation that will be carried out by students. Students are constructed as individuals who play a role as objects of knowledge and controlled subjects (Martono 2014). Body regulation in Foucault's concept emerges because of the panopticon or supervision. Panopticon according to Foucault can be implemented through three aspects, including the observation system, normalization or standardization, and the examination system. In this study, the teachers' role as a panopticon for smart class students is performed through the process as shown in Figure 1.

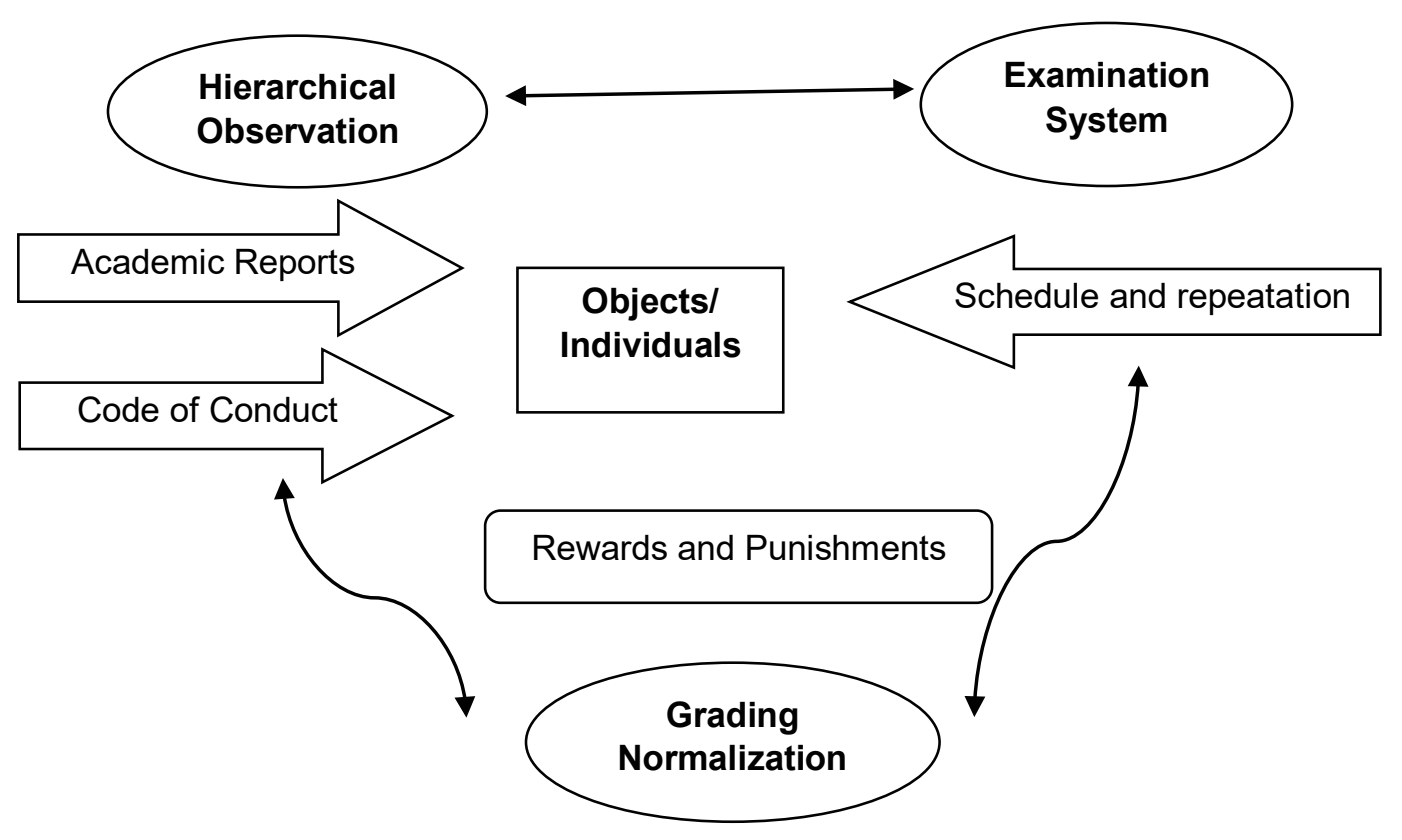

Figure 1.

Michel Foucault's individual disciplinary mechanisms

Source: Martono (2014)

\section{Hierarchical observation system: Teacher provides learning contract during distance learning}

Teachers in the school organization have a higher level of position than students, so they have the right to supervise students (Martono 2014). First, the teachers monitor the progress of students' academic achievement during online learning. The limitation to meet fa-to-face makes teachers oblige all students to turn on the camera during the online meetings from the beginning of the class until it is completed and wear uniforms appropriately. Usually, students will turn on the camera when the teacher calls their names. They feel reluctant to show their faces because they do not wear uniforms or just woke up. Therefore, the teacher requires students to wear uniforms and show their full faces during the learning process. If the camera is suddenly turned off or the student disappears, the teacher will deduct 50 percent of the total value obtained. The threat of grade deduction to 50 percent causes most smart class students to turn on the camera unless they get permission to go to the bathroom.

"At the beginning of semester 1 in the 2020/2021 school year, we have notified the school regulations. First, students must attend school according to schedule and I give a tolerance of 5-10 minutes for being late. Students who come after the tolerance time would be considered absent. Second, students are required to turn on the camera because I am afraid that they will fall asleep during class hours or are not even there. The camera must also focus on the students, not on the wall or other things. Third, it is mandatory to wear a uniform when studying and they have to get permission if they want to go to the bathroom." (MUI, mathematics teacher) 
Second, students are required to arrive on time according to the schedule set by the school, which is 07.00-08.00 for the first lesson, 08.15-09.15 for the second lesson, 09.30-10.30 for the third lesson, and 10.45-11.45 for the fourth hour. Distance learning is shorter in duration compared to offline learning, which starts from 07.00-15.15. This causes the teacher to focus on delivering the material perfectly. As a result, if students arrive late during class, they will disrupt others who are already getting lessons. Moreover, the teacher emphasizes that the tolerance is 5-10 in every change of lesson hours. This is done by the teacher to anticipate if students still are doing something like having breakfast or going to the bathroom while at home. Students who exceed this time will be considered absent and the list of those who are absent will later be recapitulated and given to the BK teachers. The counseling teachers will then submit it to the homeroom teacher if the number of absences has exceeded five times. The homeroom teacher will then ask parents to come to the school and if possible, along with counseling teachers, will visit the student's house to find out the learning problems they are experiencing. Students in the smart class will consider this embarrassing for them, especially if they are expelled from the smart class and moved to the regular class. Therefore, students who rarely turn on the camera start turning on the camera even though sometimes they still do not focus the camera on them.

\section{Normalization: Rewards and punishments as a standard for outstanding students}

Normalization or standardization that is manifested through a set of norms and grading guidelines in schools is important (Foucault in Martono 2014). Teachers use certain categories to group students who excel and who do not. Smart class students desire to be placed in the outstanding category because almost all of them have exceptional academic abilities. Smart class students have a highly competitive spirit in terms of fighting for good grades, prompting teachers to use grades as a stimulus so that all students are active during the learning process. The teacher categorizes outstanding students in several aspects. First, students have the willingness to take note of all the material presented by the teacher during the learning process as a form of appreciating the teacher who has gone to great lengths to explain the material, and eventually, the notes will be collected when preparing for the exam by showing it through the camera during the meeting.

Second, students have the willingness to be active during the learning process. This is done by the teacher by rewarding plus points to students who are willing to ask or answer the teacher's questions without having to be appointed first. Meanwhile, the teacher will give minus points to those who give wrong answers after being appointed by the teacher to answer the question and to those who do not want to answer at all or leave the online meeting without permission. For smart class students, this method makes most of them immediately ask questions to the teacher following the teacher's explanation without having to be appointed and makes the learning process active and not boring. These results are the same as the results of a study conducted by Sari \& Hadijah (2017) that rules regarding discipline in the classroom should be established by the teacher in collaboration with students, not merely as a formality, so that their relationship is closer and easier to carry out collaboratively.

\footnotetext{
"During the pandemic, grades become a threat that I use to deal with students who are starting to lose enthusiasm during the learning process. The most effective way to get students back to being diligent amid boring online learning is to reduce points for those who are late in submitting assignments and add points for those who are active during learning, such as by frequently asking and answering. I also give a penalty in the form of different grades if they don't submit assignments by the time deadline. I also don't hesitate to contact their parents if there are assignments that are not submitted." (JEN, Indonesian Teacher)
}

Third, outstanding students are those who submit assignments on time and do not cheat on exams. Teachers set a rule that students should submit assignments on time as part of the assessment. The teacher sets deadlines in Google Classroom as the limit for collecting assignments and there are certain sanctions for students who are late in submitting assignments or not submitting them at all. The teacher deducts two points and multiplies them for students who are late in submitting assignments based on the 
length of the time from the given deadline. The farther the length of time from the given deadline, the higher the deduction points. Meanwhile, for students who do not submit assignments at all, the teacher gives a consequence by announcing the names during the learning process. Smart class students will be very embarrassed if their names are mentioned as those who do not submit assignments. This is because the existing stigma in the classroom will immediately consider the student lazy or underachieving so that when they need to form a study group, the student will not be selected as a member of the group because of this trait. The teacher also asks the reason why students do not submit assignments, while also threatens to give bad grades on student report cards. This threat is extremely effective for smart class students who then promise to submit assignments soon. The teacher also offers students to choose the desired punishment if they break their promise again to submit their assignments. The teacher prefers non-physical punishment over physical ones. The students then choose to get a minimum score for their report cards and to be reported to their parents if they still do not submit assignments. These findings are in contrast to Apriyanto's research (2019) that disciplining students is not only the responsibility of the teacher but also all educators and student organizations in schools. The school also uses a digital attendance system to anticipate students who are truant and missed when the teachers call their names. Therefore, they can have a recapitulation of student data in addition to preventing students from manipulating the data by asking for help from other students.

Cheating during a test will also make smart class students fall into the category of students who are not outstanding because they are considered to have violated the rules and norms that have been established in the class. This includes cheating by asking friends or looking at notes or textbooks. The consequences obtained will always be the same, which is a reduction in a score for those who cheat and those who help others to cheat. The teacher will deduct two points and will be multiple for the same student's answers and are sorted according to the number of absences. Therefore, the student whose answer is the same and has the last absence will get more deductions compared to the other friends, although this student is the one who provides the answers. Because smart class students do not want this to happen, many of them decide to do assignments themselves even though the results will not be always good. In addition, the teacher always has one student to monitor the class group and report to the teacher if there are indications of cheating during exams.

\footnotetext{
"Essays are a type of assignment that makes it easier for teachers to identify students who are cheating. Usually, I will correct one essay answer based on the first to the last attendance number. Subsequent attendance numbers will be given fewer points if they have the same answer. For example, attendance number one gets twenty points for one answer, then the next student with the same answer will only get 18 points. And so on. If I find another same answer, I will subtract 2 until it only gets 2 points. It's certainly unfair to those who provide the answer and have the attendance number at the end. I deliberately apply this method so that they feel deterred so that they will never dare to do it again in the next regular test." (DIJ, economics teacher)
}

Another teacher's role as a panopticon is implemented by giving regular test questions in the form of essays rather than multiple choice because essay questions allow for easier identification of abilities and detecting students who cheat through the answers given. In this method, the teacher corrects the answers of the student with the first attendance number to the last sequentially. This method is used by the teacher in order to remember the answers of all students in one question so that they can give the appropriate points when they find the same answers. The teacher deliberately gives punishment in the form of a small point for students with last attendance numbers who have the same answers so that they feel deterred. Therefore, without being asked to admit their actions, they will complain to the teacher regarding their scores. This is different from the findings in a study conducted by Marice \& Taqwa (2020) that the panopticon at the Sriwijaya Sports State Senior High School is given through a point system during face-to-face learning to monitor the behavior of students and athletes while at school. Students and athletes who obey the rules will get additional points on their report cards, while those who violate the rules will receive punishment in the form of a reduction in points. Normalization is carried out by applying democratic discipline. 


\section{Exam system: Scheduled regular test and semester exam}

An exam is a representation of disciplinary supervision in schools and a representation of the mechanism of direct supervision to students. Exams are a mechanism for simultaneous evaluation and comparison that are implemented at schools through spontaneously repeated rituals of power (Foucault in Martono 2014). The exam system is realized in the form of regular tests and semester exams. The regular test is given to students every time a chapter of learning is completed. It is usually done in the form of oral or essay questions by the teacher in order to be able to measure the student's understanding of the material that has been taught. Students who can explain their responses will be categorized as smart, while students who cannot explain their answers will be categorized as less intelligent. Mid-Semester Assessment is carried out every three months aiming to monitor students' abilities for half a semester and reducing the risk that students do not understand the subject given during that semester. It is also used by the teacher to find out material that still needs to be emphasized more to students. Assignments are given to determine students' skills in solving problems. The teacher performs remedial work in order to improve students' marks in comparison to their test scores. The last is the Final Semester Assessment which is the most crucial component of grades to see the students' ability to understand the material during the semester. This test score affects the final accumulated value of the report card obtained by the student. Therefore, usually, the implementation of this exam will be carried out for one to two full weeks so that students can focus on the exam solely.

"Regular Tests and Semester Exams are mostly in the form of essays so that I can find out students
who already understand the material and are able to explain answers to those who have not. These
tests aim to measure their abilities. So, usually, the test scores I give are not pure from these tests,
but are added with the activeness in class." (KHU, English teacher, 2021)

The situation of distance learning during the COVID-19 pandemic caused the teachers of Hang Tuah Senior High School 2 of Sidoarjo to develop self-discipline for students. The teacher as the first party to interact with students applies several rules so that the essence of distance learning is not different from face-to-face learning and students' achievements can still be maintained. The self-discipline carried out by the teachers includes supervising students by applying rules by joining and leaving the online meeting on time, turning on the camera, and wearing uniforms. Furthermore, standardization of student actions is in accordance with school expectations and norms to create smart students by paying attention to the percentage between reward (additional points) and punishment (reduction of points and calling parents). The last is the evaluation of learning provided by the teachers during the COVID-19 pandemic with virtual and ongoing daily exams or tests. These three responsibilities are all performed by teachers so that students regard teachers as parties who must be obeyed and who can control students during the learning process

\section{Conclusion}

The teachers' role as a panopticon in the smart class of Hang Tuah Senior High School 2 of Sidoarjo during the COVID-19 pandemic greatly affected the implementation of distance learning (PJJ). Although the learning activities are done virtually, the teachers of Hang Tuah Senior High School 2 of Sidoarjo can still control student learning and continue to discipline student activities although they do not meet in person but through intermediaries several applications, such as Google Meet and Google Classroom. The teacher becomes a figure who is obeyed, prompting students to be willing to carry out all the rules imposed by the teacher during distance learning and receive punishment for breaking the rules. This self-discipline of students is highly useful for maintaining the quality of learning at Hang Tuah Senior High School 2 of Sidoarjo so that students do not experience a decline in academic achievement even though it must be carried out differently from the face-to-face learning, besides that, students still respect the teacher and the achievements of smart class students can still be maintained as selected outstanding students. The role of the teacher as a panopticon towards students can also be used as input for educators in other schools as a way to reduce student laziness during distance learning, hence minimizing the decline in student achievement. 


\section{References}

Aini DDN (2019) "Gerakan disiplin sekolah" (analisis praktik pendisiplinan siswa di SMP Negeri 11 Madiun dalam perspektif disiplin tubuh dan hukuman Michel Foucault). Thesis, IAIN Ponorogo, Ponorogo.

Aji RHS (2020) Dampak COVID-19 pada pendidikan di Indonesia: Sekolah, keterampilan, dan proses pembelajaran. Jurnal Sosial \& Budaya Syar-i 7 (5):395-402.

Aprilia V \& Jacky M (2019) Relasi kuasa dan CCTV di Sekolah Menengah Atas Negeri di Bojonegoro. Jurnal Paradigma 7 (4):1-6.

Apriyanto A (2019) Manajemen pembinaan kedisiplinan siswa: Studi kasus pada absensi fingerprint berbasis SMS Gateway di SMK NU Kaplongan Indramayu. Gema Wiralodra 10 (1):79-92.

Aswat H, Sari ER, Aprilia, R, Fadli A, \& Milda M (2021) Implikasi distance learning di masa pandemi COVID 19 terhadap kecerdasan emosional anak di sekolah dasar. Jurnal Basicedu 5 (2):761-771.

Aucejo EM, French JF, Araya MPU, \& Zafar B (2020) The impact of COVID-19 on student experiences and expectations: Evidence from a survey. National Bureau of Economic Research Working Paper Series.

Azevedo JP, Hasan A, Goldemberg D, Iqbal SA, \& Geven K (2020) Simulating the Potential Impacts of COVID-19 School Closures on Schooling and Learning Outcomes: A Set of Global Estimates. New York: The World Bank.

Dunn CG, Kenney E, Fleischhacker SE, \& Bleich SN (2020) Feeding low-income children during the COVID-19 pandemic. New England Journal of Medicine 382. https://doi.org/10.1056/ NEJMp2005638.

Foucault M. (1975) Discipline and Punish. New York: Vintage Books.

Foucault M (2002) Power/Knowledge: Wacana Kuasa/Pengetahuan. Yogyakarta: Bintang Budaya.

Gutting G (2005) Foucault: A very short introduction. Oxford: Oxford University Press.

Ilham FM \& Fauzi AM (2020) Relasi kuasa guru dalam pengajaran pendidikan agama Islam. Paradigma $9(2): 1-17$.

Khasanah DRAU, Pramudibyanto H, \& Widuroyekti B (2020) Pendidikan dalam masa pandemi COVID-19. Jurnal Sinestesia 10 (1):41-48.

Kurnia D (2021) Dinamika gejala kejenuhan belajar siswa pada proses belajar online faktor-faktor yang melatarbelakangi dan implikasinya pada layanan bimbingan keluarga. TEACHING: Jurnal Inovasi Keguruan Dan Ilmu Pendidikan 1 (1):1-10.

Mahapatra A \& Sharma P (2020) Education in times of COVID-19 pandemic: Academic stress and its psychosocial impact on children and adolescents in India. In International Journal of Social Psychiatry 67 (4):397-399.

Marice LD \& Taqwa R (2020) Pola kekuasaan pendisiplinan dalam membina perilaku peserta didik di SMA Negeri Olahraga Sriwijaya. Scholaria 10 (2):122-133.

Martono N (2014) Dominasi kekuasaan dalam pendidikan: Tesis Bourdieu dan Foucault tentang pendidikan. Jurnal Interaksi 8 (1):28-39.

Martono N (2014) Sosiologi Pendidikan Michel Foucault: Pengetahuan, Kekuasaan, Disiplin, Hukuman dan Seksualitas. Jakarta: Raja Grafindo Persada.

Mu'tamiroh W \& Suyanto B (2021) Hegemonic practices of online local fashion brands in the information society era during the Covid-19 pandemic. Jurnal Sosiologi Dialektika 16 (1):53-63.

Muzaenatun S (2017) Pemaksimalan fungsi pengawasan peserta didik melalui pemasangan CCTV di ruang kelas. Thesis, Universitas Negeri Semarang, Semarang.

Ningsih S (2020) Persepsi mahasiswa terhadap pembelajaran daring pada masa pandemi COVID-19. JINOTEP 7 (2):124-132.

Pajarianto H, Sari P, Kadir A, Galugu N, \& Februanti S (2020) Study from home in the middle of the COVID-19 pandemic: Analysis of religiosity, teacher, and parents support against academic stress. Journal of Talent Development and Excellence 12 (2):1791-1807.

Pfefferbaum B \& North CS (2020) Mental health and the COVID-19 pandemic. New England Journal of Medicine 383:510-512. https://doi.org/10.1056/NEJMp2008017. 
Purnama AY (2021) Solusi bias kognitif, kesenjangan digital dan moralitas di era pandemi COVID-19. Indonesian Journal Of Education dan Humanity 1 (1):63-68.

Rinawati D \& Darisman EK (2020) Survei tingkat kejenuhan siswa SMK belajar di rumah pada mata pelajaran produk kreatif dan kewirausahaan selama masa pandemi COVID-19. Journal of Science and Education 1 (1):32-40.

Ritzer G \& Goodman DJ (2014). Teori Sosiologi: Dari Teori Sosiologi Klasik sampai Perkembangan Mutakhir Teori Sosial Postmodern. Bantul: Kreasi Wacana.

Sari BP \& Hadijah HS (2017) Meningkatkan disiplin belajar siswa melalui manajemen kelas. Jurnal Pendidikan Manajemen Perkantoran 2 (2):233-241.

SMA Hang Tuah 2 Sidoarjo (2020) Pembelajaran jarak jauh di SMA Hang Tuah 2 Sidoarjo. [Accessed 25 January 2021]. https://smahangtuah2sda.sch.id/artikel/pembelajaran-jarak-jauh-sma-hangtuah-2.

Sunardi \& Fatihin K (2019) Pola interaksi guru dengan peserta didik perspektif Al-Qur'an Surah Luqman ayat 12-19. Journal of Islamic Education Annaba 5 (2):201-206.

Suryanto AB (2020) Genealogi pesantren dalam manuskrip Tantu Panggelaran. Journal of Islamic Civilization 2 (1):1-7.

Triwiyanto (2020) Bukan sekedar subsidi pulsa, untuk mengurangi angka putus sekolah dampak pandemi COVID-19. Seminar Nasional Fakultas Pendidikan Universitas Negeri Malang 325-335.

Yanti FN \& Sumianto (2021) Analisis faktor-faktor yang menghambat minat belajar di masa pandemi COVID-19 pada siswa SDN 008 Salo. Jurnal Pendidikan Tambusai 5 (1):608-614.

Zaki M (2018) Fenomena kekuasaan politik dan eksistensi gender dalam perkembangan pendidikan. Jurnal Sosial, Politik, Kajian Islam dan Tafsir 1 (1):1-17. 